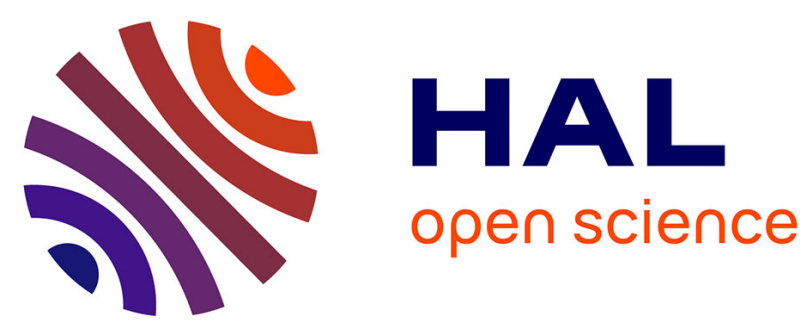

\title{
Synthesis, characterization, catalytic and biological application of half-sandwich ruthenium complexes bearing hemilabile $(\kappa 2-\mathrm{C}, \mathrm{S})$-thioether-functionalised NHC ligands
}

\author{
Weighang Chen, Julien Egly, Amalia I Poblador-Bahamonde, Aline \\ Maisse-Francois, Stéphane Bellemin-Laponnaz, Thierry Achard
}

\section{To cite this version:}

Weighang Chen, Julien Egly, Amalia I Poblador-Bahamonde, Aline Maisse-Francois, Stéphane Bellemin-Laponnaz, et al.. Synthesis, characterization, catalytic and biological application of halfsandwich ruthenium complexes bearing hemilabile $(\kappa 2-\mathrm{C}, \mathrm{S})$-thioether-functionalised NHC ligands. Dalton Transactions, 2020, 49 (10), pp.3243-3252. 10.1039/C9DT04825A . hal-02998170

\section{HAL Id: hal-02998170 https://hal.science/hal-02998170}

Submitted on 10 Nov 2020

HAL is a multi-disciplinary open access archive for the deposit and dissemination of scientific research documents, whether they are published or not. The documents may come from teaching and research institutions in France or abroad, or from public or private research centers.
L'archive ouverte pluridisciplinaire HAL, est destinée au dépôt et à la diffusion de documents scientifiques de niveau recherche, publiés ou non, émanant des établissements d'enseignement et de recherche français ou étrangers, des laboratoires publics ou privés. 


\section{Synthesis, characterization, catalytic and biological application of half-sandwich ruthenium complexes bearing hemilabile (k2-C,S)- thioether-functionalised NHC ligands.}

\section{Introduction}

Since the pioneering work of Murahashi ${ }^{1}$ and Milstein ${ }^{2}$ on acceptorless dehydrogenation (AD) type amidation, numerous groups have explored this exciting catalytic-type reaction. ${ }^{3}$ Ruthenium has been established as the metal of choice for this highly atom-economic and environmentally friendly transformation. ${ }^{4}$ Consequently, a wide-array of Ru-based catalyst systems have been developed for the dehydrogenation of alcohol.3a, 3b, 3d, 5 In this context, Rucomplexes bearing $\mathrm{N}$-Heterocyclic carbenes (NHCs), as synthetically accessible and highly tuneable ligand, ${ }^{6}$ either generated in situ $^{7}$ or well-defined, ${ }^{8}$ are particularly interesting for this process. It is noteworthy to mention that NHC-Ru catalytic system has been successfully applied with great effectiveness to amination reaction as recently disclose by Huynh et al. ${ }^{9}$ Interestingly, addition of $\mathrm{PPh}_{3}$ is frequently required with monodentate $\mathrm{NHC}$-based systems to enhance the catalytic activity. ${ }^{7 a}, 7 \mathrm{e}, 8 \mathrm{a}, 8 \mathrm{c}, 8 \mathrm{e}, 8 \mathrm{f} \mathrm{N}$-functionalized NHCs with an additional donor group (typically $\mathrm{P}, \mathrm{O}$ or $\mathrm{N}$ ) have become an important class of bidentate ligand due to the possible hemilabile behaviour of their Lewis base moiety. ${ }^{10}$ Few successful examples of bidentate NHC-pyrimidine, ${ }^{11}$ naphtylridine, ${ }^{12}$-picolyl, ${ }^{13}$-phosphine ${ }^{14}$ and phenyl $\left(\mathrm{C}^{\mathrm{NHC}} \mathrm{C}\right)^{81,15}$ $\mathrm{Ru}($ arene) complexes have been reported for such acceptorless/borrowing hydrogen reactions.

Applying this AD strategy on amine is providing access to very important class of molecule namely: imine ${ }^{16}$ and nitrile. ${ }^{17,} 18$ In contrast with alcohols, highly selective dehydrogenations of amine mediated by transition metal are rare. ${ }^{3 e, 19}$ Reports on the double dehydrogenation of primary amines to produce nitriles and $\mathrm{H}_{2}$ gas as the sole by-product are even scarcer. ${ }^{19}$ Among those examples, catalysts achieve either low conversion $^{20}$ or require exogenous additives (bases and/or sacrificial hydrogen acceptor) ${ }^{21}$ with high reaction temperature and only few avoid the use of excess oxidant or aerobic conditions. ${ }^{22}$ Furthermore, the competition between the second dehydrogenation and the transamination pathway often lead to selectivity issues. ${ }^{3 e}, 4$ Nevertheless, this straightforward strategy represents a much delicate and greener alternative to classic nitrile syntheses which often suffer from certain limitation such as harsh reaction condition, use of toxic agent, poor selectivity or poor atom economy. ${ }^{22-23}$ So far, we are aware of only two examples for selective baseand oxidant-free acceptorless double dehydrogenation of primary amines. The first example, developed by Szymczak and co-workers, is implying a Rull-(NNN) pincer complex which highly favoured the nitrile pathway. ${ }^{24}$ The second one, recently expose by our group, is describing the use of simple $[\mathrm{Ru}(p-$ cym) $\left.\mathrm{Cl}_{2}\right]_{2}$ as pre-catalyst. ${ }^{25}$ The addition of a strong base was found necessary to achieve both high reactivity and selectivity for the Ru"-pyrazole/ $t$-BuOK catalytic system described by Bera and co-workers. ${ }^{26}$ Very recently, the combination of an external base/hydride source (hexamethylenetetramine) and the $\left[\mathrm{Ru}(p-c y m) \mathrm{Cl}_{2}\right]_{2}$ pre-catalyst, reported by Mathaiah et al., generate good nitrile selectivity even for benzylamine derivatives. ${ }^{27}$ Finally, various well defined monodentate NHC$\mathrm{Ru}$ catalysts have been developed by Mata et al. for this transformation albeit with moderate nitrile selectivity. ${ }^{28}$ 
In this context, we wondered if the straight formation of coordinatively more rigid cationic complexes using bidentate NHC ligands instead of triphenylphosphine could generate more active and robust catalysts. Among the different types of donor-functionalized NHC hybrids ligands ( $\mathrm{N}, \mathrm{O}$, and $\mathrm{P}), \mathrm{S}-$ functionalized NHCs still remain an undeveloped class of ligands. ${ }^{10 e,} 29$ Interestingly, thioether-functionalized NHCs, associated to transition metal $\left(\mathrm{Cu},{ }^{30} \mathrm{Ni}^{31} \mathrm{Pd},{ }^{32} \mathrm{Pt}^{33} \mathrm{Rh}^{31 \mathrm{a}}, 34\right.$ \& $\mathrm{Ru}^{34 \mathrm{~b}}$ ), have proven to be efficient in several catalytic system. $30-31,32 c, 32 \mathrm{e}, 32 \mathrm{j}, 321,33 \mathrm{c}$ Among these, only one NHC$\mathrm{Ru}(\mathrm{cym})$ thioether catalyst was reported and applies to the catalytic hydrogenation of styrene and 1-dodecene. ${ }^{35}$

Herein we report the synthesis of a series of bidentate thioether-functionalized $\mathrm{N}$-heterocyclic carbenes precursors with various $-S R$ substituents. The corresponding cationic NHC-ruthenium complexes were prepared from $[\mathrm{Ru}(p-$ cym) $\left.\mathrm{Cl}_{2}\right]_{2}$ generating exclusively chelate complexes with a $\kappa^{2}-$ $(C, S)$ coordination mode. The stereochemistry issue of complexes were studied by a combination of variable temperature (VT) ${ }^{1} \mathrm{H}-\mathrm{NMR}$ experiments, X-ray diffraction studies and DFT calculations. Studies on the catalytic activity and selectivity of these NHC-Ru complexes have been conducted on the double dehydrogenation of amine without the use of any additional oxidant. Under optimized conditions, alkyl amines were transformed into nitrile with good selectivity. Finally, the cytotoxicity of relevant NHC-Ru complexes was evaluated on various cancer cell-lines.

\section{Results and discussion}

Synthesis and characterization of the cationic C,S-chelated ruthenium complexes (1a-l)

The S-functionalized imidazolium precursors a-I have been synthesized in two steps starting from benzyl imidazole. Reaction of benzyl imidazole with 1,2-dibromoethane provided 1-benzyl-3-bromoethylimidazolium bromide, which was next quantitatively functionalized by reacting with the desired thiolate (see ESI for details). NHC-ruthenium complexes 1a-I were obtained from corresponding imidazolium salts a-I by a classic transmetalation pathway between the silver-carbene intermediate and $\left[\mathrm{Ru}(p-c y m) \mathrm{Cl}_{2}\right]_{2}$. Subsequently, the anion exchange between $\mathrm{Br}^{-}$and $\mathrm{PF}_{6}{ }^{-}$was followed by purification by chromatography on silica gel to afford complexes $\mathbf{1}$ a-j in good yields (Figure 1).

All complexes were obtained as orange to dark orange microcrystalline powder and are air-stable in solid state. The formation of the $[(\mathrm{NHC}) \mathrm{Ru}(\mathrm{p}-\mathrm{cym}) \mathrm{Cl}]\left[\mathrm{PF}_{6}\right]$ complexes 1a-I was established by the disappearance of the typical proton signal between $\delta$ 9-11 ppm assigned to the $2 \mathrm{H}$-imidazolium in the ${ }^{1} \mathrm{H}$ NMR spectrum and also by the appearance of a signal between $\delta 165-170 \mathrm{ppm}$ in the ${ }^{13} \mathrm{C}$ NMR spectrum, which corresponds to the ruthenium carbene carbon. The analytical data (HRMS, $\left.{ }^{1} \mathrm{H} N M R\right)$ advocated for the coordination of NHC in a chelate $\kappa^{2}-(\mathrm{C}, \mathrm{S})$ fashion which was later unambiguously confirmed by $\mathrm{X}$-ray analysis on single crystal (vide infra). ${ }^{36}$
Figure 1. Synthesis of cationic chelated ruthenium complexes 1a-I.

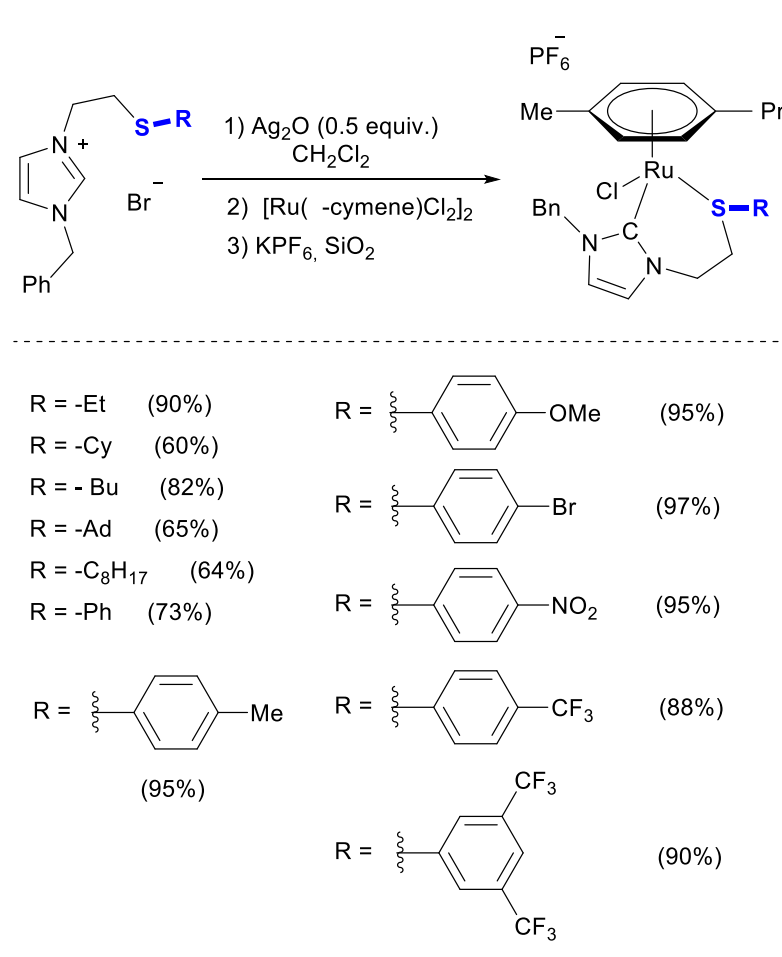

The ${ }^{1} \mathrm{H}$ NMR spectra of all complexes compared to the spectra of imidazolium precursors display a marked difference in the region between 2.4 and $4.9 \mathrm{ppm}$ which correspond to the $\mathrm{NCH}_{2} \mathrm{CH}_{2} \mathrm{~S}$ - moiety. This observation is consistent with ligands that bind in a $\kappa^{2}-(\mathrm{C}, \mathrm{S})$-chelating fashion, rendering the $-\mathrm{CH}_{2} \mathrm{~N}$ and $-\mathrm{CH}_{2} \mathrm{~S}$ - protons diastereotopic in the newly formed metallacycle. The signals of the two protons of each $\mathrm{N}-\mathrm{CH}_{2}$ and $\mathrm{S}-\mathrm{CH}_{2}$ are now split into two sets of two different multiplets. We observe for each case that one of $\mathrm{N}-\mathrm{CH}_{2}$ and $\mathrm{S}-\mathrm{CH}_{2}$ protons is slightly deshielded while the other and more strongly shielded compared to free ligand $\left(\Delta \delta+0.07 /-0.8 \mathrm{ppm}\right.$ for $\mathrm{S}-\mathrm{CH}_{2}$ and $\Delta \delta+0.11 /-0.65$ ppm for $\mathrm{N}-\mathrm{CH}_{2}$ ).

Surprisingly, instead of a complex diastereomeric mixture that would result of the presence of two stereogenic centers on the sulfur and the metal center and associated to possible dynamic processes namely sulphur inversion or its hemilability, 33 a, 37,38 only one isomer is observed in solution in all cases. The situation could be even more complicated considering the formation of the six-membered ring between metal and ligand whose different conformations could generate as well a dynamic process in solution. ${ }^{39}$

\section{X-ray analyses}

Single crystals suitable for X-ray diffraction analysis of $\mathbf{1 c}, \mathbf{1} \mathbf{i}$ and $\mathbf{1 j}$ were obtained by slow diffusion of diethyl ether into concentrated solution of complexes in dichloromethane (1/3). The molecular structure of the three complexes are depicted in Figure 2 along with key bond lengths and bond angles. ${ }^{40}$ All these complexes display the expected three-legged piano-stool 
geometry around the ruthenium center. As a result of the coordination of the pro-chiral thioether, two stereocenters are present and consequently a diastereomeric mixture may be expected. For the three structures, only one enantiomeric pair $\left(R_{\mathrm{Ru}} S_{\mathrm{S}} / S_{\mathrm{Ru}} R_{\mathrm{S}}\right)$ of complex was found in the solid state. ${ }^{41}$ The $\mathrm{R}$ group of the thioether is oriented in anti-position with respect to the $p$-cymene ligand as a consequence of steric repulsions. This geometry forces the thioether to adopt a single configuration and thus disfavoured the formation of the enantiomeric couple $R_{\mathrm{Ru}} R_{\mathrm{S}} / S_{\mathrm{Ru}} S_{\mathrm{S}}$ in the solid state. The RuCarbene bond distance of complexes $1 \mathrm{c}, 1 \mathrm{i}$ and $1 \mathrm{j}$ are in the range of other $\mathrm{NHC}$-Ru(p-cymene) complexes which are in between 2.02-2.09 $\AA .8 \mathrm{~d}, 13,28,34 \mathrm{~b}, 35 \mathrm{a}, 42 \mathrm{Ru}-\mathrm{S}$ bond distances are in the range to those describe in the literature for thioetherRu(p-cymene) complexes. ${ }^{37 f,} 43$ However, these bonds lengths are longer compared to the one observed for the two chelates $\mathrm{NHC} /$ thioether ruthenium complexes reported so far. ${ }^{34 \mathrm{~b},} 35 \mathrm{a}$ Considering the standard deviation calculated for these RuCarbene and Ru-S bonds lengths (see figure 2), no significant differences can be drawn from these value. The larger value observed in complexes 1c-1i for the $\langle\mathrm{S}-\mathrm{Ru}-\mathrm{C}\rangle$ angle (89.1$90.3^{\circ}$ ) compared to $84.6^{\circ}$ in complex $1 \mathbf{j}$ is most likely related to the difference in conformation of the 6-membered chelate ring which is half-chair when $\mathrm{R}=t \mathrm{Bu}$ or $p-\mathrm{Br}-\mathrm{C}_{6} \mathrm{H}_{4}$ and boat conformation when $\mathrm{R}=p-\mathrm{NO}_{2}-\mathrm{C}_{6} \mathrm{H}_{4}$.

(a)

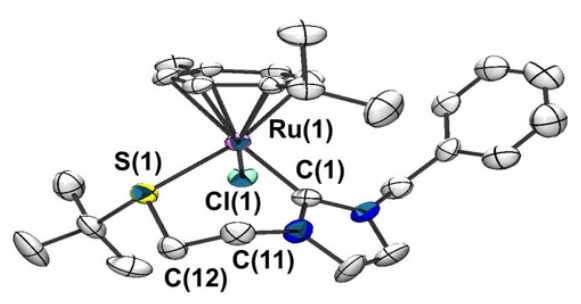

(b)

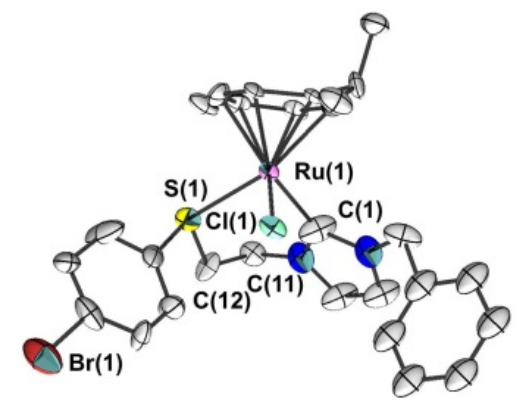

(c)

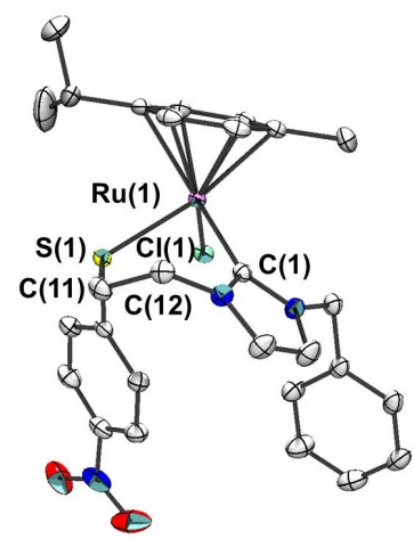

Figure 2. Molecular structure of ruthenium NHC complexes $\mathbf{1 c}, \mathbf{1} \mathbf{i}$ and $\mathbf{1 j}$. Selected bond distances $(\AA ̊)$ and angles ( ${ }^{\circ}$ : : 1c (a) CCDC $n^{\circ} 1957068: R u(1)-C(1), 2.075(7) ; R u(1)-S(1)$, 2.398(2); R(1)-CI(1), 2.407(2); Ru-Cym cent (1.721); Cl(1)-Ru(1)-S(1), 95.27(7); S(1)-Ru(1)$C(1), 90.3(2) ; C(1)-R u(1)-C I(1), 86.8(2) .1 \mathbf{i}(b) C C D C n^{\circ}$ 1957070: $R u(1)-C(1), 2.050(15)$; $\mathrm{Ru}(1)-\mathrm{S}(1), 2.384(4) ; \mathrm{R}(1)-\mathrm{Cl}(1), 2.395(3) ; \mathrm{Ru}^{-} \mathrm{Cym}_{\text {cent }}(1.720) ; \mathrm{Cl}(1)-\mathrm{Ru}(1)-\mathrm{S}(1), 91.2(1)$; $\mathrm{S}(1)-\mathrm{Ru}(1)-C(1), 89.1(4) ; C(1)-R u(1)-C l(1), 87.6(4) .1 \mathrm{j}$ (c) CCDC n'1957069 : Ru(1)-C(1), 2.0592(14); Ru(1)-S(1), 2.3891(14); R(1)-CI(1), 2.4061(5); Ru-Cym cent(1.724); Cl(1)-Ru(1)$S(1), 87.77(1) ; S(1)-R u(1)-C(1), 84.62(4) ; C(1)-R u(1)-C l(1), 92.16(4)$.

\section{DFT Calculation}

All signals in ${ }^{1} \mathrm{H}$ NMR were sharp and well-defined which was not expected thinking about the possible dynamic isomeric mixtures in solution. These analyses suggest either that, in solution, these Ru-species might a display dynamic stereochemical rearrangement, or that the $\mathrm{Ru}$ complex formation is diastereoselective. In order to gather insight into the system, computational studies were conducted. Three substituents were chosen for this study $(-t \mathrm{Bu}, \mathbf{1 c},-\mathrm{Ph}, \mathbf{1 f}$ and $\mathrm{CF}_{3}$, labelled as $\left.\mathbf{1}_{\mathrm{CF} 3}\right)$. First, we optimized the $\mathrm{R}_{\mathrm{Ru}} / \mathrm{S}_{\mathrm{S}}$ configuration corresponding to complex $1 \mathrm{c}$ base on the solid state structure. Energy optimizations for $\mathbf{1 c}$ and $\mathbf{1}_{\mathrm{CF} 3}$ were performed using the same starting point (See ESI for computational details). Optimized structures were also computed for the $R_{R u} / R_{S}$ diastereomers corresponding to the inversion of configuration at the sulfur atom. Such configuration was found more stable for complexes $\mathbf{1} \mathbf{c}$ and $\mathbf{1}_{\mathrm{CF} 3}$ and slightly less stable for complex $\mathbf{1 f}$ (Figure 3 ).

The next step, was the search of the inversion path at the sulfur atom throughout two possible processes: i) an intramolecular pyramidal inversion mechanism without bond rupture (Figure 3 ) or ii) a dissociative/associative mechanism (Figure 4). Both pathways were investigated and they are discussed below. In addition, the influence of the substituents on the thioether group was also analyzed. 


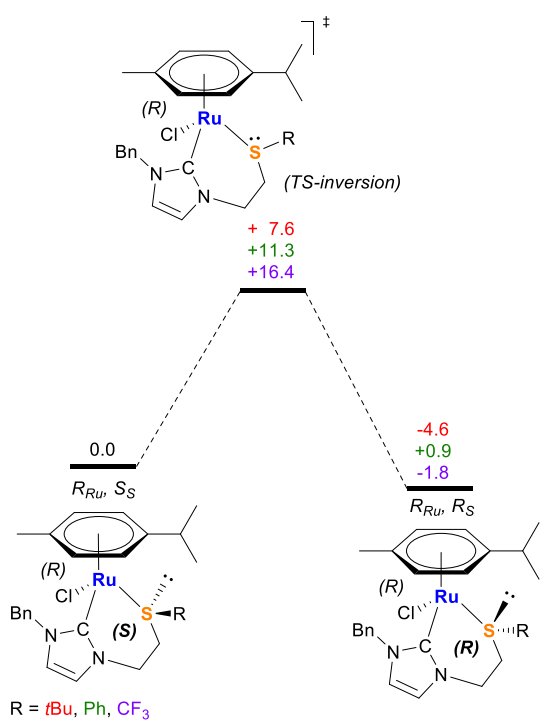

Figure 3. Calculated sulfur pyramidal inversion pathway for $\mathbf{1 c}$ (red), $\mathbf{1 f}$ (green) and $\mathbf{1}_{\mathrm{CF} 3}$ (black) (values in Kcal mol-1. The $\mathrm{PF}_{6}{ }^{-}$anion was omitted for clarity).

The calculations established that sulfur inversion trough pyramidal inversion might be favored and relatively easy for $\mathrm{S}$ $t \mathrm{Bu}$ and $\mathrm{S}$-Ph groups $\left(+7.6 \leq \Delta \mathrm{G}^{\ddagger} \leq+11.3 \mathrm{kcal}^{\mathrm{mol}}{ }^{-1}\right.$ ) (Figure 3) compared to the dissociative/associative pathway in which the second step, recoordination of the sulphur atom, is the limiting step of the reaction and an unfavorable process $\left(+15.8 \leq \Delta \mathrm{G}^{\ddagger} \leq\right.$ $+18.2 \mathrm{kcal} \mathrm{mol}^{-1}$ ) (Figure 4).

Interestingly, this trend is reversed in the presence of the strong electron withdrawing group as $-\mathrm{CF}_{3}$ for which the dissociative/associative pathway $\left(\Delta \mathrm{G}^{\ddagger}=6.1 \mathrm{kcal} \mathrm{mol}^{-1}\right)$ is now favored by more than $10.3 \mathrm{kcal} \mathrm{mol}^{-1}$ compared to the pyramidal inversion. The presence of this strong electronwithdrawing group at the sulfur atom further weakens the SRu bond favoring the dissociative/associative mechanism.

This counterintuitive result might be explained by the analysis of the Ru-S distances on the intermediate and TS2coordination. The optimized geometry on the intermediate features Ru-S distances over $5 \AA$ for $\mathrm{R}=t$ - $\mathrm{Bu}$ and $\mathrm{Ph}(5.51 \AA$ and $5.20 \AA$, respectively) with the substituent placed far from the $p$-cym ligand in order to minimize steric hindrance. In the case of $\mathrm{R}=\mathrm{CF}_{3}$, the Ru-S distance is $4.92 \AA$ and the substituent is closer to the $p$-cym ligand. The second step, TS2coordination, model for $\mathrm{R}=t$ - $\mathrm{Bu}$ and $\mathrm{Ph}$ the shortening of the Ru-S distance by $1.97 \AA(R=t-B u)$ and $1.56 \AA$ ( $R=P h)$ plus the rotation of the substituent away from the $p$-cym ligand while $R$ $=\mathrm{CF}_{3}$ mainly model a shortening of $1.35 \AA$. This observation highlight that the re-coordination step seems to depend on both, the shortening of the Ru-S distance and the minimization of the steric hindrance between the substituent and the $p$-cym ligand being more demanding for $\mathrm{R}=t-\mathrm{Bu}$ and $\mathrm{Ph}$ than for $\mathrm{R}=$ $\mathrm{CF}_{3}$.

Overall, the calculations predict a fast and easy dynamic sulfur inversion, which is too fast for NMR timescale at $298 \mathrm{~K}$ what is coherent with the observation of only one species in solution by ${ }^{1} \mathrm{H}$ NMR. Nevertheless, studies on the relative higher activation barrier computed for $1 \mathbf{f}(\Delta \mathrm{G} \ddagger=+11.3 \mathrm{kcal} \mathrm{mol}-1)$, suggests the possible experimental observation of two diastereoisomers by variable temperature NMR (details discussed in the following section).

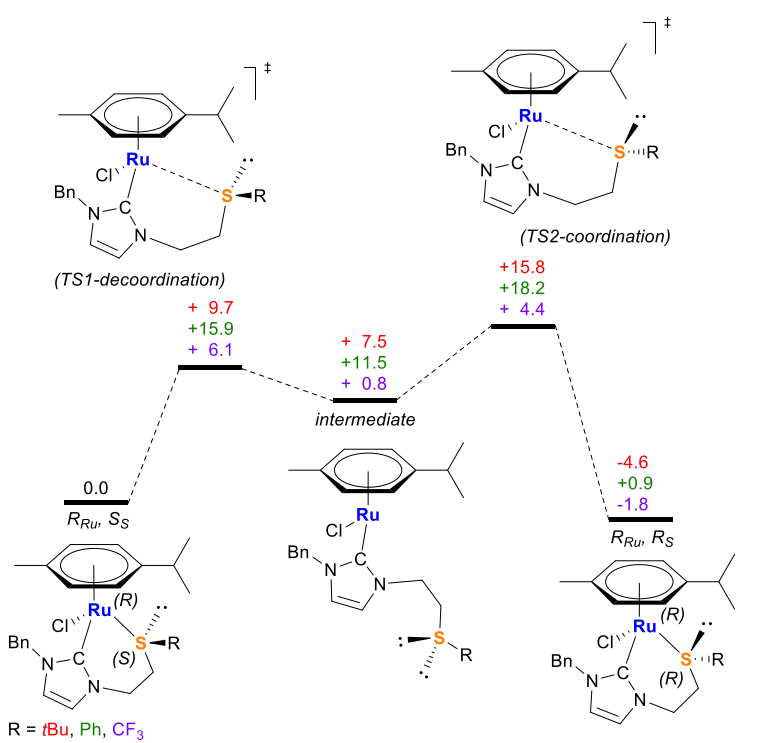

Figure 4. Calculated dissociative/associative pathway for $\mathbf{1 c}$, $\mathbf{1}$ and $\mathbf{1}_{\mathrm{CF} 3}$ (values in Kcal $\mathrm{mol}^{-1}$. The $\mathrm{PF}_{6}{ }^{-}$anion was omitted for clarity).

\section{VT-NMR experiments}

More insights in the possible dynamic processes were obtained by variable-temperature ${ }^{1} \mathrm{H}$ NMR studies of the compounds in $\mathrm{CD}_{2} \mathrm{Cl}_{2}$ in the range of $298-198 \mathrm{~K}$ and in 1,2dichlorobenzene- $d_{4}$ in the range of 298-378 K.

For complex 1c (-t-Bu), increasing (up to $378 \mathrm{~K}$ ) or decreasing (up to $198 \mathrm{~K}$ ) the temperature did not display any additional signals. These results may indicate that compound $1 \mathrm{c}$ has a fixed stereochemical rearrangement without decoordination and a low activation barrier for Sulphur inversion in agreement with the DFT calculations. In consequence, the variabletemperature ${ }^{1} \mathrm{H}$ NMR experiments of complex 1 f $(-\mathrm{Ph})$ now display a different feature at low temperature. Four multiplets corresponding to the $\mathrm{N}-\mathrm{CH}_{2}-\mathrm{CH}_{2}-\mathrm{S}$ chain which integrate for one proton and the $\mathrm{CH}_{3}$ peaks of cymene integrating for three protons became broader as the temperature decreased and de-coalesced at $248 \mathrm{~K}$, before splitting into sharp signals. At $193 \mathrm{~K}$, we observed a 2/1 diastereomeric mixture and no triplet signals corresponding to uncoordinated thioether species were observed (see ESI for details). These results are consistent with the previous DFT calculations (see Figure 3 ). Finally, the free energy of activation $\left(\Delta G^{\ddagger}\right)$ for this process based on the coalescence temperature of the $\mathrm{SCH}_{2}$ group is of ca. $11.2 \mathrm{kcal} \mathrm{mol}^{-1}$ and $11.9 \mathrm{kcal} \mathrm{mol}^{-1}$ based on the $\mathrm{CH}_{3}$ of the cymene group which is also in agreement with the theoretical studies (i.e. $11.3 \mathrm{kcal} \mathrm{mol}^{-1}$, Figure 3). ${ }^{44}$

The low temperature VT-NMR was also carried out on complex 1l which contains $2-\mathrm{CF}_{3}$ withdrawing groups and could be compared with the computed $-\mathrm{SCF}_{3}$ group by the calculation. Once again, no de-coalescence was noticed even at $193 \mathrm{~K}$ for 
this complex. The only mechanism fairly consistent with experimental and theoretical data appears to be the pyramidal inversion without any Ru-S bond dissociation for both 1c and 1f complexes.

\section{Application to catalysis: oxidation of primary amine to nitrile under oxidant free conditions}

In a first set of experiments, the dehydrogenation of benzylamine into benzonitrile was chosen as benchmark reaction and complex $\mathbf{1 c}$ was originally selected for optimizing the experimental conditions. The best conditions were obtained by varying the temperature, solvents and additives (See ESI table S1). Finally, the reactions were performed using $2.5 \mathrm{~mol} \%$ of Ru-complex and $0.2 \mathrm{mmol}$ of benzylamine in 0.2 $\mathrm{mL}$ of 1,2-dichlorobenzene (ODCB) at $110^{\circ} \mathrm{C}$ in an open vessel under inert atmosphere. With this combination, high conversion was observed after $24 \mathrm{~h}$ and the benzonitrile was generated as the major compound with some imine product both confirmed by ${ }^{1} \mathrm{H}$ NMR and GC analysis (see ESI table S1). Control experiments showed that in absence of the catalyst no reaction occurred and that only traces of imine were detected in a close system ${ }^{8 e}$ under these experimental conditions. ${ }^{25,45}$ In contrast to previous reports, ${ }^{26-27}$, the presence of either weak or strong base have no or slight effect on both the nitrile/imine ratio and reactivity. ${ }^{28}$

The NHC-Ru complexes 1a-I bearing thioether groups with different electronic and steric properties, that may affect coordination with the ruthenium center, were next evaluated under the optimized standard conditions (Table 1). ${ }^{46}$ All cationic catalysts were found active generating a mixture of nitrile and imine products. Overall, it emerges that catalysts bearing an electron donating alkyl group are more active than those having aryl groups. Only the aryl-complex $\mathbf{1}$ reaches the same level of reactivity of bulky alkyl type complexes (Entry 13). ${ }^{47}$ The same trend was observed for the selectivity of the reaction for which complex $\mathbf{1 c}(\mathrm{S}-t \mathrm{Bu})$ displayed the highest nitrile ratio (Entry 3 ) and complex $\mathbf{1 i}(\mathrm{p}-\mathrm{Br})$ the highest imine ratio (Entry 10). Either, bulky or long alkyl chains have a detrimental effect on the formation of nitriles. In addition, aromatic substitutions by strong electron donating or withdrawing groups are both unpropitious for nitrile selectivity (Entries 8-13). Finally, alkyl groups with the strongest $\sigma$ donating power generate the nitrile as major product of the reaction (Entries 1-3).
Table 1. Evaluation of benzylamine oxidation in presence of NHC-Ru complexes. $^{\text {a }}$

$$
\mathrm{PhCH}_{2} \mathrm{NH}_{2} \underset{\substack{110{ }^{\circ} \mathrm{C}, 24 \mathrm{~h} \\ \text { 1,2-dichlorobenzene }}}{2.5 \mathrm{~mol} \%[\mathrm{Ru}]} \underbrace{\mathrm{CN}}_{\mathbf{2}}+\mathrm{Ph}_{3}
$$

\begin{tabular}{|c|c|c|c|c|c|c|}
\hline \multirow[t]{2}{*}{ Entry } & \multirow[t]{2}{*}{$\mathrm{Ru}$} & \multirow[t]{2}{*}{$\mathrm{R}^{1}$} & \multirow[t]{2}{*}{$\mathrm{R}^{2}$} & \multirow{2}{*}{$\begin{array}{l}\text { Conv } \\
(\%)^{[b]}\end{array}$} & \multicolumn{2}{|c|}{ Selectivity (\%) ${ }^{[b]}$} \\
\hline & & & & & 2 & 3 \\
\hline 1 & $1 a$ & Et & $\mathrm{Bn}$ & 77 & 55 & 45 \\
\hline 2 & $1 b$ & Cy & $\mathrm{Bn}$ & 92 & 57 & 43 \\
\hline 3 & $1 c$ & $t-\mathrm{Bu}$ & $\mathrm{Bn}$ & 90 & 60 & 40 \\
\hline 5 & 1d & $\mathrm{Ad}$ & $\mathrm{Bn}$ & 90 & 50 & 50 \\
\hline 6 & $1 e$ & $n$-Oct & $\mathrm{Bn}$ & 84 & 48 & 52 \\
\hline 7 & 1f & $\mathrm{Ph}$ & $\mathrm{Bn}$ & 89 & 40 & 60 \\
\hline 8 & $1 \mathrm{~g}$ & $p-\mathrm{Me}\left(\mathrm{C}_{6} \mathrm{H}_{4}\right)$ & $\mathrm{Bn}$ & 88 & 50 & 50 \\
\hline 9 & 1h & $p$-OMe $\left(\mathrm{C}_{6} \mathrm{H}_{4}\right)$ & $\mathrm{Bn}$ & 70 & 40 & 60 \\
\hline 10 & $1 \mathbf{i}$ & $p-\mathrm{Br}\left(\mathrm{C}_{6} \mathrm{H}_{4}\right)$ & $\mathrm{Bn}$ & 72 & 37 & 63 \\
\hline 11 & $1 \mathrm{j}$ & $p-\mathrm{NO}_{2}\left(\mathrm{C}_{6} \mathrm{H}_{4}\right)$ & $\mathrm{Bn}$ & 72 & 44 & 56 \\
\hline 12 & $1 k$ & $p-\mathrm{CF}_{3}\left(\mathrm{C}_{6} \mathrm{H}_{4}\right)$ & $\mathrm{Bn}$ & 88 & 54 & 46 \\
\hline 13 & 11 & $3,5-\mathrm{CF}_{3}\left(\mathrm{C}_{6} \mathrm{H}_{3}\right)$ & $\mathrm{Bn}$ & 92 & 50 & 50 \\
\hline 14 & 4 & $t-\mathrm{Bu}$ & $\mathrm{CH}_{3}$ & 98 & 65 & 35 \\
\hline 15 & 5 & $t-\mathrm{Bu}$ & $\mathrm{CH}_{3}$ & 90 & 39 & 61 \\
\hline
\end{tabular}

[a] Reaction conditions: benzylamine $(0.2 \mathrm{mmol}), 2.5 \mathrm{~mol} \%$ cat. based on Ru and 1,2dichlorobenzene $(0.2 \mathrm{~mL}), 110{ }^{\circ} \mathrm{C}, 24 \mathrm{~h}$, open vessel under argon atmosphere; [b] Conversion and selectivity were determined by ${ }^{1} \mathrm{H}$ RMN hexadecane as internal reference.

In the dehydrogenative amidation of alcohol and amine catalyzed by NHC-Ru systems, it has been shown that the reactivity and the selectivity are sensitive to the $\mathrm{N}$ substitution $^{7 \mathrm{a}, 7 \mathrm{~b}}$ of the NHCs and that benzimidazole ${ }^{8 \mathrm{~g}, 8 \mathrm{k}, 81,9}$ core displays often better activity than imidazole counterpart. A second generation catalysts were synthesized and evaluated, under our catalytic conditions, to address these two points (Figure 5). First, steric effect on the nitrogen of the NHCs was assessed through the complex 4, which has a methyl group instead of the benzyl group. The catalyst showed the highest reactivity and selectivity (entry 14). Secondly, the corresponding benzimidazole complex $\mathbf{5}$ also promotes this transformation but in contrast to its imidazole analogue 1c, catalyst $\mathbf{5}$ favors the formation of imine rather than nitrile products (Entry 15). 

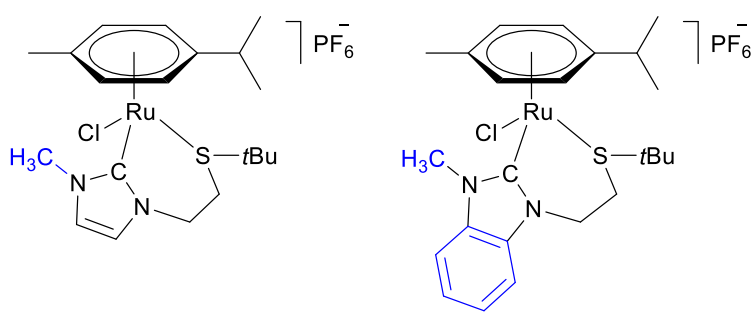

Figure 5. Steric and electronic variations: molecular structure of complexes $\mathbf{4}$ and $\mathbf{5 .}$

We then decided to further use complex $\mathbf{1 c}$ to investigate the scope and limitations of the catalytic double dehydrogenation of primary amines (Figure 6). On primary amines, irrespective of the nature of the alkyl chain (long, branched or saturated), the formation of the corresponding nitrile was formed exclusively. Thereby good yields were obtained after purification on $\mathrm{SiO}_{2}$. Substrates with unsaturated alkene functions were also used and the corresponding products were obtained in good yield. However the kinetic of the reaction was dependent on the length of the alkyl chain; for example the octadecylamine required $120 \mathrm{~h}$ of reaction time to achieve full conversion. Benzylamine derivatives were also investigated albeit with low selectivity and formation of imines. Electronrich benzylamine derivative 16 showed the best nitrile selectivity compared to electron-poor substrates. Consequently the lower yields obtained for these benzylic derivatives are mainly due to poorest selectivity and also issues during the purification step. ${ }^{48}$ Globally, these results show the difficulty to control the factors that govern the selectivity of the reaction with benzylamine derivatives. The uses of several NHC-S ligands were found quasi-ineffective for the discrimination of the two products formed. Even if those cationic complexes display slight better nitrile selectivity for aliphatic amines than neutral monodentate NHCs their presence on the coordination sphere of the metal inhibit somehow the catalytic reactivity and selectivity compared to the simple ligand-free $\left[\mathrm{Ru}(p-c y m) \mathrm{Cl}_{2}\right]_{2}$ complex. ${ }^{25}, 27$ However Szymczak showed that the presence of an appropriate ligand on ruthenium could achieved, under oxidant-free conditions, high level of both reactivity and selectivity for activated amines. ${ }^{24}$ Therefore, further efforts onto the design of more active and selective ligands are thus required for such challenging substrates.

Figure 6. Reaction scope of primary amines double hydrogenation with catalyst $1 c^{\text {a }}$

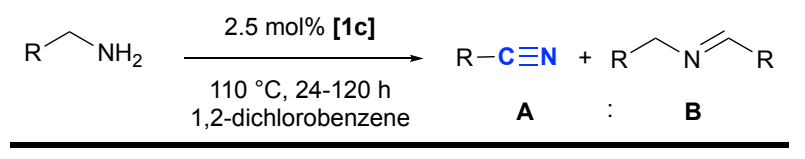

$$
\begin{aligned}
& \mathbf{6}, \mathrm{n}=4, \mathrm{n} . \mathrm{d} ., 24 \mathrm{~h}(1: 0) \\
& \begin{array}{l}
\mathbf{7}, \mathrm{n}=6,80 \%, 30 \mathrm{~h}(1: 0) \\
\mathbf{8}, \mathrm{n}=10,65 \%, 35 \mathrm{~h}(1: 0) \\
\mathbf{9}, \mathrm{n}=12,71 \%, 48 \mathrm{~h}(1: 0)
\end{array} \\
& \mathbf{1 0}, \mathrm{n}=16,50 \%, 120 \mathrm{~h}(1: 0)
\end{aligned}
$$

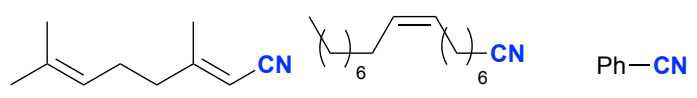$$
13,60 \% \quad 24,50 \%
$$

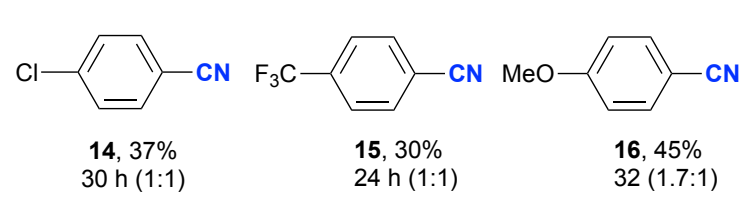

[a] Isolated yields; A:B ratio in parenthesis.

To gain more insight into the reaction mechanism, an equimolar mixture of benzylamine and complex 1c was dissolved in $\mathrm{CD}_{2} \mathrm{Cl}_{2}$ at room temperature, and followed by ${ }^{1} \mathrm{H}$ NMR experiments. Interestingly, the spectra displayed no change after 24 hours, even in the presence of 10 equivalents of amine and heating up to $60{ }^{\circ} \mathrm{C}$ for 6 hours. In order to be closer than the reaction conditions, complex $\mathbf{1 c}$ was heated at $110{ }^{\circ} \mathrm{C}$ in the presence of two equivalents of benzylamine in deuterated ODCB (in a closed system). After two hours no changes were observed. Interestingly however after longer time (18 h), free cymene was identified with a ratio Ru- $p$ cym/free cym of $4 / 1$ in solution. When the reaction was set up with ten equivalents of benzylamine at $110{ }^{\circ} \mathrm{C}$ for $24 \mathrm{~h}$, we observed an almost complete dissociation of the cymene (see ESI fig. S13), ${ }^{49}$ and the NHC ligand remained attached to the metal center (see ESI). This observation, in line with previous reports, indicates that the $p$-cymene complex is probably not involved in the catalytic cycle. ${ }^{8 f, 9,13}$ Even if, no clear evidence of amine coordination was detected in the ${ }^{1} \mathrm{H}$ NMR spectrum, the observation of imine suggests that this process should take place (see ESI). In the presence of the only imine product and the ruthenium complex $\mathbf{1 c}$, under our standard conditions, no reaction occurred after $24 \mathrm{~h}$.

To avoid the dehydrogenation pathway the tert-octylamine, which cannot undergo the elimination process, was also used. Once again, no displacement of either -StBu or $\mathrm{Cl}^{-}$was observed even after $24 \mathrm{~h}$ at $110^{\circ} \mathrm{C}$ in ODCB, suggesting that the starting complex is a highly stable resting state.

\section{In vitro activity of selected Ru NHC complexes}

Ruthenium complexes are of great attention in the development of metal-based anticancer compounds. ${ }^{50}$ Some ruthenium(II) $p$-cymene have shown good antiproliferative activities against various cancer cell lines and also low systemic 
toxicity. ${ }^{50}$ In addition, $\mathrm{N}$-heterocyclic carbene ligands are of particular interest in the field of medicinal inorganic chemistry. 33d, 51 They allowed generating robust complexes even in the presence of water and they fit many prerequisites for easy optimization.

Antiproliferative activities of some representative ruthenium complexes described here, namely $\mathbf{1 a}, \mathbf{1 d}, \mathbf{1}$ and $\mathbf{1}$, were measured on a panel of three different human tumor cell lines (namely MCF7, HCT116 and PC3) (IC $C_{50}$, Entries 1-4, Table 2). Complexes 1a (-Et) and 1f (-Ph) displayed activities in the range 50-75 $\mu \mathrm{M}$. On the other hand, complexes $\mathbf{1 d}(-\mathrm{Ad})$ and $\mathbf{1}$ ( $\left(-3,3^{\prime}-\right.$ $\mathrm{CF}_{3}-\mathrm{C}_{6} \mathrm{H}_{3}$ ) showed good activities (up to $3.5 \mu \mathrm{M}$ ). These results are most likely connected with the lipophilicity 52 of the complexes since adamantane ${ }^{53}$ or fluorine-containing ${ }^{54}$ substituents are known to enhance the overall lipophilicity of the molecule.

Table 2 Half inhibitory concentrations $I_{50}$ (in $\mu \mathrm{M}$ ) of the selected $R u$ compounds against human cancer cell lines. ${ }^{a}$

\begin{tabular}{llccc}
\hline Entry & Compound & HCT116 & MCF7 & PC3 \\
\hline 1 & 1a & $56.9 \pm 11.2$ & $75.9 \pm 3.05$ & $74.3 \pm 10.8$ \\
2 & 1d & $4.90 \pm 0.19$ & $14.3 \pm 0.94$ & $3.54 \pm 0.23$ \\
3 & 1f & $49.1 \pm 1.77$ & $57.2 \pm 6.96$ & $65.7 \pm 13.8$ \\
4 & 1l & $9.79 \pm 0.19$ & $12.8 \pm 2.23$ & $10.01 \pm 1.02$
\end{tabular}

${ }^{a}$ after $72 \mathrm{~h}$ of incubation; stock solutions in DMSO for all complexes.

Stability in solution of the compounds is an important requirement in medicinal chemistry. Because solutions were prepared in DMSO/water, these results should be correlated with the stability of the ruthenium complexes in solution, which could easily be monitored by ${ }^{1} \mathrm{H}$ NMR or UV-vis. Investigation of the complexes stability by NMR in a $1 / 1$ mixture of dmso- $d_{6}$ and $\mathrm{D}_{2} \mathrm{O}$, revealed no change after 4 days and the complexes remained intact.

\section{Conclusions}

In summary, we have developed a variety of well-defined thioether-functionalized $\mathrm{N}$-heterocyclic carbene $\left(\kappa^{2}-\mathrm{C}, \mathrm{S}\right)-\mathrm{Ru}(\mathrm{II})$ $\eta^{6}$-cymene cationic Ru complexes by varying the substituents of the thioether. Surprisingly the solid state spectroscopy analysis display only one ruthenium specie as an enantiomeric couple rather than the expected diastereomeric mixture. Despite this, a very fast sulphur inversion at room temperature was established by a combination of VT ${ }^{1} \mathrm{H}$ NMR experiments and DFT calculations which might account for a dynamic stereochemical rearrangement which would be responsible to the presence of fluxional mixtures at room temperature as observed by ${ }^{1} \mathrm{H}$ NMR spectroscopy. In addition these calculations indicated that donating groups on the sulfur atom favored the intramolecular pyramidal inversion mechanism while electron withdrawing group favored the dissociative/associative pathway. Through a systematic investigation of the ligand structures and various reaction conditions, the cationic ruthenium complex 1c was found to be the most active catalyst for the double dehydrogenation of primary amine to give the corresponding nitrile under oxidantand base-free conditions. With these bidendate NHCs, high selectivity has been achieved using aliphatic amines and only a poor to no selectivity was obtained with benzylamine derivatives. Investigation on the active species clearly indicated the decoordination of $p$-cymene. Finally, these ruthenium complexes showed promising cytotoxic activities on several human cancer cells. We are currently further evaluating their biomedical properties varying the nature and the complexity of the systems in order to improve the cytotoxic profile and selectivity of the resulting complexes.

\section{Conflicts of interest}

There are no conflicts to declare.

\section{Acknowledgements}

This research was funded in part by La Ligue Contre le Cancer-Grand-Est and by the University of Strasbourg/CNRS-Program IDEX Interdisciplinaire. We will also like to thank the University of Geneva ( $U$ of $G$ ) for financial support and Carmine Chiancone ( $U$ of $G$ ) for technical support.

\section{Notes and references}

1 T. Naota and S. I. Murahashi, Synlett, 1991, 693-694.

2 C. Gunanathan, Y. Ben-David and D. Milstein, Science, 2007, 317, 790-792.

3 (a) G. E. Dobereiner and R. H. Crabtree, Chem. Rev., 2010, 110, 681-703; (b) C. Gunanathan and D. Milstein, Science, 2013, 341; (c) C. Gunanathan and D. Milstein, Chem. Rev., 2014, 114, 12024-12087; (d) R. H. Crabtree, Chem. Rev., 2017, 117, 9228-9246; (e) A. Corma, J. Navas and M. J. Sabater, Chem. Rev., 2018, 118, 1410-1459.

4 C. Chen, F. Verpoort and Q. Y. Wu, RSC Advances, 2016, 6, 55599-55607.

5 (a) T. C. Johnson, D. J. Morris and M. Wills, Chem. Soc. Rev., 2010, 39, 81-88; (b) P. Pandey, I. Dutta and J. K. Bera, Proc. Natl. Acad. Sci., India, Sect. A Phys. Sci., 2016, 86, 561-579; (c) S. Siddiki, T. Toyao and K. Shimizu, Green Chem., 2018, 20, 2933-2952.

6 (a) L. Benhamou, E. Chardon, G. Lavigne, S. BelleminLaponnaz and V. Cesar, Chem. Rev., 2011, 111, 27052733; (b) M. N. Hopkinson, C. Richter, M. Schedler and F. Glorius, Nature, 2014, 510, 485-496; (c) M. C. Jahnke and F. E. Hahn, in $\mathrm{N}$-Heterocyclic Carbenes: From Laboratory Curiosities to Efficient Synthetic Tools (2), The Royal Society of Chemistry, 2017, pp. 1-45.

7 (a) L. U. Nordstrom, H. Vogt and R. Madsen, J. Am. Chem. Soc., 2008, 130, 17672-+; (b) S. C. Ghosh, S. Muthaiah, Y. Zhang, X. Y. Xu and S. H. Hong, Adv. Synth. Catal., 2009, 351, 2643-2649; (c) S. Muthaiah, S. C. Ghosh, J. E. Jee, C. Chen, J. Zhang and S. H. Hong, J. Org. Chem., 2010, 75, 3002-3006; (d) S. C. Ghosh and S. H. Hong, Eur. J. Org. Chem., 2010, 4266-4270; (e) J. Zhang, M. Senthilkumar, S. C. Ghosh and S. H. Hong, Angew. Chem. Int. Ed., 2010, 49, 6391-6395; (f) C. 
Chen, M. H. Kim and S. H. Hong, Org. Chem. Front. 2015, 2, 241-247; (g) H. Guo, Y. Wang, G. F. Du, B. Dai and L. He, Tetrahedron, 2015, 71, 3472-3477; (h) C. Chen, Y. Miao, K. De Winter, H. J. Wang, P. Demeyere, Y. Yuan and F. Verpoort, Molecules, 2018, 23; (i) H. Cheng, M. Q. Xiong, C. X. Cheng, H. J. Wang, Q. Lu, H. F. Liu, F. B. Yao, C. Chen and F. Verpoort, Chem. Asian J., 2018, 13, 440-448.

8 (a) J. H. Dam, G. Osztrovszky, L. U. Nordstrom and R. Madsen, Chem. Eur. J, 2010, 16, 6820-6827; (b) Y. Zhang, C. Chen, S. C. Ghosh, Y. X. Li and S. H. Hong, Organometallics, 2010, 29, 1374-1378; (c) C. Chen, Y. Zhang and S. H. Hong, J. Org. Chem., 2011, 76, 1000510010; (d) A. Maggi and R. Madsen, Organometallics, 2012, 31, 451-455; (e) A. Prades, E. Peris and M. Albrecht, Organometallics, 2011, 30, 1162-1167; (f) I. S. Makarov, P. Fristrup and R. Madsen, Chem. Eur. J, 2012, 18, 15683-15692; ( $g$ ) J. Malineni, C. Merkens, H. Keul and M. Moller, Catal. Commun., 2013, 40, 80-83; (h) N. Ortega, C. Richter and F. Glorius, Org. Lett., 2013, 15, 1776-1779; (i) B. Saha, G. Sengupta, A. Sarbajna, I. Dutta and J. K. Bera, J. Organomet. Chem., 2014, 771, 124-130; (j) K. Kim, B. Kang and S. H. Hong, Tetrahedron, 2015, 71, 4565-4569; (k) H. Cheng, M. Q. Xiong, N. Zhang, H. J. Wang, Y. Miao, W. Su, Y. Yuan, C. Chen and F. Verpoort, ChemCatChem, 2018, 10, 43384345; (I) X. J. Wu, H. J. Wang, Z. Q. Yang, X. S. Tang, Y. Yuan, W. Su, C. Chen and F. Verpoort, Org. Chem. Front., 2019, 6, 563-570.

9 X. K. Xie and H. V. Huynh, ACS Catal., 2015, 5, 41434151.

10 (a) O. Kuhl, Chem. Soc. Rev., 2007, 36, 592-607; (b) A. T. Normand and K. J. Cavell, Eur. J. Inorg. Chem., 2008, 2781-2800; (c) W. H. Zhang, S. W. Chien and T. S. A. Hor, Coord. Chem. Rev., 2011, 255, 1991-2024; (d) S. Hameury, P. de Fremont and P. Braunstein, Chem. Soc. Rev., 2017, 46, 632-733; (e) E. Peris, Chem. Rev., 2018, 118, 9988-10031.

11 D. Gnanamgari, E. L. O. Sauer, N. D. Schley, C. Butler, C. D. Incarvito and R. H. Crabtree, Organometallics, 2009, 28, 321-325.

12 B. Saha, S. M. W. Rahaman, P. Daw, G. Sengupta and J. K. Bera, Chem. Eur. J, 2014, 20, 6542-6551.

13 F. E. Fernandez, M. C. Puerta and P. Valerga, Organometallics, 2012, 31, 6868-6879.

14 W. H. Chang, X. Gong, S. Z. Wang, L. P. Xiao and G. Y. Song, Org. Biomol. Chem., 2017, 15, 3466-3471.

15 Z. Q. Wang, X. S. Tang, Z. Q. Yang, B. Y. Yu, H. J. Wang, W. Sang, Y. Yuan, C. Chen and F. Verpoort, Chem. Commun., 2019, 55, 8591-8594.

16 (a) R. W. Layer, Chem. Rev., 1963, 63, 489-510; (b) S. Kobayashi and H. Ishitani, Chem. Rev., 1999, 99, 10691094; (c) S. F. Martin, Pure Appl. Chem., 2009, 81, 195204; (d) M. E. Belowich and J. F. Stoddart, Chem. Soc. Rev., 2012, 41, 2003-2024.

17 (a) F. F. Fleming, Nat. Prod. Rep., 1999, 16, 597-606; (b) F. F. Fleming, L. Yao, P. C. Ravikumar, L. Funk and B. C. Shook, J. Med. Chem., 2010, 53, 7902-7917.

18 (a) P. Pollak, G. Romeder, F. Hagedorn, H-P. Gelbke, in Nitriles. In Ullmann's Encyclopedia of Industrial Chemistry; Wiley-VCH: Weinheim, Germany, 2012. (b) A. Kleemann, J. Engel, B. Kutscher, D. Reichert, in Pharmaceutical Substances: Syntheses Patents, Applications, 4th edn., Georg Thieme Verlag, Stuttgart, 2001. (c) Comprehensive Organic Transformations: a Guide to Functional Group Preparations, (Ed.: R. C. Larock), Wiley-VCH, Weinheim, 1989, pp. 819-995. (d) A. J. Fatiadi, in Preparation and Synthetic Applications of Cyano Compounds, (Eds.: S. Patai, Z. Rappoport), Wiley-VCH, New York, 1983.

19 D. L. J. Broere, Phy. Sci. Rev., 2018, 3.

20 T. Yoshida, T. Okano and S. Otsuka, J. Chem. Soc., Chem. Commun., 1979, 870-871.

21 (a) X.-Q. Gu, W. Chen, D. Morales-Morales and C. M. Jensen, J. Mol. Catal. A: Chem., 2002, 189, 119-124; (b) W. H. Bernskoetter and M. Brookhart, Organometallics, 2008, 27, 2036-2045; (c) Z. Wang, J. Belli and C. M. Jensen, Faraday Discuss., 2011, 151, 297-305.

22 M. T. Schuemperli, C. Hammond and I. Hermans, ACS Catal., 2012, 2, 1108-1117.

23 (a) T. Sandmeyer, Ber. Dtsch. Chem. Ges., 1884, 17, 1633-1635; (b) K. W. Rosenmund and E. Struck, Ber. Dtsch. Chem. Ges., 1919, 52, 1749-1756; (c) F. Porta, C. Crotti, S. Cenini and G. Palmisano, J. Mol. Catal., 1989, 50, 333-341; (d) S. Yamazaki and Y. Yamazaki, Bull. Chem. Soc. Jpn., 1990, 63, 301-303; (e) W. P. Griffith, B. Reddy, A. G. F. Shoair, M. Suriaatmaja, A. J. P. White and D. J. Williams, J. Chem. Soc., Dalton Trans., 1998, 2819-2825; $(f)$ V. V. Zhdankin and P. J. Stang, Chem. Rev., 2008, 108, 5299-5358; (g) S. Aiki, A. Taketoshi, J. Kuwabara, T.-a. Koizumi and T. Kanbara, J. Organomet. Chem., 2011, 696, 1301-1304; (h) J. Kim, H. J. Kim and S. Chang, Angew. Chem. Int. Ed., 2012, 51, 1194811959; (i) J. Kim and S. S. Stahl, ACS Catal., 2013, 3, 1652-1656; (j) G. B. Yan, Y. Zhang and J. B. Wang, Adv. Synth. Catal., 2017, 359, 4068-4105; (k) R. Ray, A. S. Hazari, G. K. Lahiri and D. Maiti, Chem. Asian J., 2018, 13, 2138-2148; (I) T. Najam, S. S. A. Shah, K. Mehmood, A. U. Din, S. Rizwan, M. Ashfaq, S. Shaheen and A. Waseem, Inorg. Chim. Acta, 2018, 469, 408-423.

24 (a) K. N. T. Tseng, A. M. Rizzi and N. K. Szymczak, J. Am. Chem. Soc., 2013, 135, 16352-16355; (b) K. N. T. Tseng and N. K. Szymczak, Synlett, 2014, 25, 2385-2389; (c) L. V. A. Hale, T. Malakar, K.-N. T. Tseng, P. M. Zimmerman, A. Paul and N. K. Szymczak, ACS Catal., 2016, 6, 4799-4813.

25 T. Achard, J. Egly, M. Sigrist, A. Maisse-Francois and S. Bellemin-Laponnaz, Chem. Eur. J, 2019, 25, 1327113274.

26 I. Dutta, S. Yadav, A. Sarbajna, S. De, M. Holscher, W. Leitner and J. K. Bera, J. Am. Chem. Soc., 2018, 140, 8662-8666.

27 M. Kannan and S. Muthaiah, Organometallics, 2019, 38, 3560-3567.

28 D. Ventura-Espinosa, A. Marza-Beltran and J. A. Mata, Chem. Eur. J, 2016, 22, 17758-17766.

29 (a) M. Bierenstiel and E. D. Cross, Coord. Chem. Rev., 2011, 255, 574-590; (b) D. Yuan and H. V. Huynh, Molecules, 2012, 17, 2491-2517; (c) C. Fliedel and P. Braunstein, J. Organomet. Chem., 2014, 751, 286-300; (d) C. Fliedel, A. Labande, E. Manoury and R. Poli, Coord. Chem. Rev., 2019, 394, 65-103.

30 A. Szadkowska, E. Zaorska, S. Staszko, R. Pawlowski, D. Trzybinski and K. Wozniak, Eur. J. Org. Chem., 2017, 4074-4084.

31 (a) J. Wolf, A. Labande, J. C. Daran and R. Poli, Eur. J. Inorg. Chem., 2007, 5069-5079; (b) J. C. Bernhammer and H. V. Huynh, Organometallics, 2014, 33, 58455851; (c) F. Ulm, A. I. Poblador-Bahamonde, S. Choppin, S. Bellemin-Laponnaz, M. J. Chetcuti, T. Achard and V. Ritleng, Dalton Trans., 2018, 47, 17134-17145.

32 (a) H. V. Huynh, C. H. Yeo and G. K. Tan, Chem. Commun., 2006, 3833-3835; (b) A. Ros, D. Monge, M. Alcarazo, E. Alvarez, J. M. Lassaletta and R. Fernandez, Organometallics, 2006, 25, 6039-6046; (c) M. Kuriyama, R. Shimazawa and R. Shirai, Tetrahedron, 
2007, 63, 9393-9400; (d) S. J. Roseblade, A. Ros, D. Monge, M. Alcarazo, E. Alvarez, J. M. Lassaletta and R. Fernandez, Organometallics, 2007, 26, 2570-2578; (e) M. Kuriyama, R. Shimazawa, T. Enomoto and R. Shirai, J. Org. Chem., 2008, 73, 6939-6942; (f) C. Fliedel, G. Schnee and P. Braunstein, Dalton Trans., 2009, 24742476; (g) H. V. Huynh, C. H. Yeo and Y. X. Chew, Organometallics, 2010, 29, 1479-1486; (h) C. Fliedel, A. Sabbatini and P. Braunstein, Dalton Trans., 2010, 39, 8820-8828; (i) L. Canovese, F. Visentin, C. Levi, C. Santo and V. Bertolasi, J. Organomet. Chem., 2013, 732, 2739; (j) D. Krishnan, M. Y. Wu, M. Y. Chiang, Y. X. Li, P. H. Leung and S. A. Pullarkat, Organometallics, 2013, 32, 2389-2397; (k) Q. Q. Teng, D. Upmann, S. Wijaya and H. V. Huynh, Organometallics, 2014, 33, 3373-3384; (I) J. C. Bernhammer and H. V. Huynh, Organometallics, 2014, 33, 1266-1275; (m) L. Canovese, F. Visentin, T. Scattolin, C. Santo and V. Bertolasi, Polyhedron, 2016, 119, 377-386.

33 (a) D. Krishnan, S. A. Pullarkat, M. Y. Wu, Y. X. Li and P. H. Leung, Chem. Eur. J, 2013, 19, 5468-5475; (b) M. S. Rosen, C. L. Stern and C. A. Mirkin, Chem. Sci., 2013, 4, 4193-4198; (c) J. C. Bernhammer and H. V. Huynh, Organometallics, 2014, 33, 172-180; (d) J. Egly, M. Bouche, W. Chen, A. Maisse-Francois, T. Achard and S. Bellemin-Laponnaz, Eur. J. Inorg. Chem., 2018, 159-166.

34 (a) H. Seo, H. Park, B. Y. Kim, J. H. Lee, S. U. Son and Y. K. Chung, Organometallics, 2003, 22, 618-620; (b) A. Labande, J. C. Daran, N. J. Long, A. J. P. White and R. Poli, New J. Chem., 2011, 35, 2162-2168.

35 (a) C. Gandolfi, M. Heckenroth, A. Neels, G. Laurenczy and M. Albrecht, Organometallics, 2009, 28, 51125121; (b) S. Horn and M. Albrecht, Chem. Commun., 2011, 47, 8802-8804.

36 The non coordination of sulfur atom was never observed in our case for strong withdrawing group SR in contrast with litterature :(a) M. J. Wiester, A. B. Braunschweig, H. Yoo and C. A. Mirkin, Inorg. Chem., 2010, 49, 7188-7196; (b) M. S. Rosen, A. M. Spokoyny, C. W. Machan, C. Stern, A. Sarjeant and C. A. Mirkin, Inorg. Chem., 2011, 50, 1411-1419.

37 (a) G. Tresoldi, L. Baradello, S. Lanza and P. Cardiano, Eur. J. Inorg. Chem., 2005, 2423-2435; (b) S. G. Murray and F. R. Hartley, Chem. Rev., 1981, 81, 365-414; (c) E. W. Abel, S. K. Bhargava, K. Kite, K. G. Orrell, V. Šik and B. L. Williams, Polyhedron, 1982, 1, 289-298; (d) E. G. Hope and W. Levason, Coord. Chem. Rev., 1993, 122, 109-170; (e) G. Tresoldi, S. Lo Schiavo, S. Lanza and P. Cardiano, Eur. J. Inorg. Chem., 2002, 181-191; (f) J. Cubrilo, I. Hartenbach, F. Lissner, T. Schleid, M. Niemeyer and R. F. Winter, J. Organomet. Chem., 2007, 692, 1496-1504; (g) P. J. Heard, Chem. Soc. Rev., 2007, 36, 551-569.

38 E.W. Abel, S.K. Bhargava, K.G. Orrell, in: S.J. Lippard (Ed.), Progress in Inorganic Chemistry, vol. 32, Wiley, 1984, p. 1.

39 M. S. Meijer and S. Bonnet, Inorg. Chem., 2019, 58, 11689-11698.

40 The crystallographic data for complexes 1c (CCDC 1957068), 1i (CCDC 1957070), and 1j (CCDC 1957069) have been deposited with the Cambridge Crystallographic Data Centre. These data can be obtained free of charge at www.ccdc.ac.uk/data\request/cif

41 Modified CIP rules were used, here the polyhapto ligand $(p-c y m)$ is considered pseudo-atoms of atomic weight equal to the sum of the atomic weights of all the atoms bonded to the metal atom (molecular weight 72). As a consequence, the following priority sequence applies for all complexes: $\eta^{6}$ - $p$-cymene $>\mathrm{Cl}>$ $\mathrm{S}>\mathrm{C}_{\text {Carb. }}$. For more information see : (a) C. Lecomte, $\mathrm{Y}$. Dusausoy, J. Protas, J. Tirouflet and A. Dormond, J. Organomet. Chem., 1974, 73, 67-76 (b) K. Stanley, M. C. Baird, J. Am. Chem. Soc., 1975, 97, 6598-6599. (c) E. B. Bauer Chem.Soc. Rev.,2012, 41, 3153-3167.

42 M. Poyatos, A. Maisse-Francois, S. Bellemin-Laponnaz, E. Peris and L. H. Gade, J. Organomet. Chem., 2006, 691, 2713-2720; (b) W. W. N. O, A. J. Lough and R. H. Morris, Organometallics, 2009, 28, 6755-6761; (c) W. Ghattas, H. M. Bunz and M. Albrecht, Organometallics, 2010, 29, 6782-6789; (d) W. B. Cross, C. G. Daly, Y. Boutadla and K. Singh, Dalton Trans., 2011, 40, 97229730; (e) X. Q. Guo, Y. N. Wang, D. Wang, L. H. Cai, Z. X. Chen and X. F. Hou, Dalton Trans., 2012, 41, 1455714567; (f) X. L. Liu and W. Z. Chen, Dalton Trans., 2012, 41, 599-608; $(g)$ H. Ohara, W. W. N. O, A. J. Lough and R. H. Morris, Dalton Trans., 2012, 41, 8797-8808; (h) V. Leigh, W. Ghattas, R. Lalrempuia, H. Muller-Bunz, M. T. Pryce and M. Albrecht, Inorg. Chem., 2013, 52, 53955402; (i) E. Jansen, L. S. Jongbloed, D. S. Tromp, M. Lutz, B. de Bruin and C. J. Elsevier, ChemSusChem, 2013, 6, 1737-1744; (j) S. K. Gupta, S. K. Sahoo and J. Choudhury, Organometallics, 2016, 35, 2462-2466; (k) S. Saha, M. Kaur, K. Singh and J. K. Bera, J. Organomet. Chem., 2016, 812, 87-94; (I) C. Chen, S. L. Ni, Q. Zheng, M. F. Yu and H. X. Wang, Eur. J. Inorg. Chem., 2017, 616-622; (m) D. L. Gerlach, S. Siek, D. B. Burks, J. M. Tesh, C. R. Thompson, R. M. Vasquez, N. J. White, M. Zeller, D. B. Grotjahn and E. T. Papish, Inorg. Chim. Acta, 2017, 466, 442-450; (n) S. Movassaghi, S. Singh, A. Mansur, K. K. H. Tong, M. Hanif, H. U. Holtkamp, T. Sohnel, S. M. F. Jamieson and C. G. Hartinger, Organometallics, 2018, 37, 4172-4172; (o) N. Marozsan, H. Horvath, E. Kovats, A. Udvardy, A. Erdei, M. Purgel and F. Joo, Molecular Catalysis, 2018, 445, 248-256.

43 (a) N. Taguchi, K. Kashiwabara, K. Nakajima, H. Kawaguchi and K. Tatsumi, J. Organomet. Chem., 1999, 587, 290-298; (b) R. Y. C. Shin, G. K. Tan, L. L. Koh and L. Y. Goh, Organometallics, 2004, 23, 6293-6298; (c) D. P. Halbach and C. G. Hamaker, J. Organomet. Chem., 2006, 691, 3349-3361; (d) C. G. Hamaker and D. P. Halbach, Inorg. Chim. Acta, 2006, 359, 846-852; (e) Y. Ohki, Y. Takikawa, H. Sadohara, C. Kesenheimer, B. Engendahl, E. Kapatina and K. Tatsumi, Chem.- Asian J., 2008, 3, 1625-1635; (f) C. G. Hamaker and D. P. Halbach, Polyhedron, 2009, 28, 2228-2232; (g) M. J. Page, J. Wagler and B. A. Messerle, Organometallics, 2010, 29, 3790-3798; (h) M. Hirotsu, A. Yogi and I. Kinoshita, Acta Crystallogr. E, 2011, 67, M63-+; (i) O. Prakash, K. N. Sharma, H. Joshi, P. L. Gupta and A. K. Singh, Dalton Trans., 2013, 42, 8736-8747; (j) J. Patalenszki, L. Biro, A. C. Benyei, T. R. Muchova, J. Kasparkova and P. Buglyo, RSC Advances, 2015, 5, 8094-8107.

44 (a) H. S. Gutowsky and C. H. Holm, J. Chem. Phys., 1956, 25, 1228-1234; (b) M. Rickhaus, L. Jundt and M. Mayor, Chimia, 2016, 70, 192-202.

45 K.-N. T. Tseng, J. W. Kampf and N. K. Szymczak, Organometallics, 2013, 32, 2046-2049.

46 The reaction time has been set at $24 \mathrm{~h}$ for which the complex 1c generates only $90 \%$ conversion.

47 (a) M. J. Wiester, A. B. Braunschweig, H. Yoo and C. A. Mirkin, Inorg. Chem., 2010, 49, 7188-7196; (b) M. S. Rosen, A. M. Spokoyny, C. W. Machan, C. Stern, A. 
Sarjeant and C. A. Mirkin, Inorg. Chem., 2011, 50, 14111419.

48 Imines are easily hydrolysed into aldehyde derivatives during the purification on column chromatography and therefor are difficult to separate from the desired nitrile products.

49 The reaction has been purposely conducted in a closed system to shut down the formation of nitrile.

50 (a) G. Gasser, I. Ott and N. Metzler-Nolte J. Med. Chem. 2011, 54, 2-35 ; (b) . Zeng, P. Gupta, Y. Chen, E. Wang, L. Ji, H. Chao and Z. S. Chen Chem. Soc. Rev 2017, 46, 5771-5804.

51 (a) K. M. Hindi, M. J. Panzner, C. A. Tessier, C. L. Cannon and W. J. Youngs, Chem. Rev., 2009, 109, 3859-3884; (b) S. Bellemin-Laponnaz Eur. J. Inorg. Chem. 2019, DOI: 10.1002/ejic.201900960

52 (a) F. Aman, M. Hanif, W.A. Siddiqui, A. Ashraf, L.K. Filak, J. Reynisson, T. Söhnel, S. M.F. Jamieson and C.G. Hartinger Organometallics 2014, 19, 5546-5553.; (b) G. Lv, L. Guo, L. Qiu, H. Yang, T. Wang, H. Liu and J. Lin Dalton Trans., 2015, 44, 7324-7331

53 (a) B. E. Smart, Characteristics of C-F Systems. In Organofluorine Chemistry, Principles and Commercial Applications; Banks, R. E.,Smart, B. E., Tatlow, J. C., Eds.; Plenum Press: New York, 1994; pp57-88.; (b) E. P. Gillis, K. J. Eastman, M. D. Hill, D. J. Donnelly, N. A. Meanwell, J. Med. Chem. 2015, 58, 8315-8359. (c) W.K. Hagmann J. Med. Chem. 2008, 51, 15, 4359-4369. (d) B. E. Smart, J. Fluorine Chem. 2001, 109, 3-11.

54 (a) J. Liu, D. Obando, V. Liao, T. Lifa, R. Codd; Eur. J. Med. Chem. 2011, 46, 1949-1963. (b) L. Wanka, K. lqbal, P. R. Schreiner; Chem. Rev. 2013, 113, 35163604. 